\title{
By what mechanism do leeches help to salvage ischaemic tissues? A review
}

\author{
I.S. Whitaker ${ }^{a, *}$, C.K. Cheung ${ }^{\mathrm{b}}$, C.A.A. Chahal', R.O.S. Karoo ${ }^{\text {, }}$, \\ A. Gulatie, I.T.H. Foo f \\ a Department of Otolaryngology and Head and Neck Surgery, Leeds General Infirmary, Leeds, UK \\ b Department of General Medicine, St James University Hospital, Leeds, UK \\ c Department of Surgery, Leeds General Infirmary, Leeds, UK \\ d Plastic Surgery and Burns Research Unit, Bradford University, UK \\ e Department of Haematology, Queen's Medical Centre, Nottingham, UK \\ ${ }^{f}$ Bradford University Hospitals NHS Trust, Bradford, UK
}

Accepted 14 September 2004

Available online 26 January 2005

\begin{abstract}
Summary The therapeutic use of leeches in medicine dates back to 50 b.c. and was cited by ancient authors. The medicinal leech, Hirudo medicinalis, has been used with increasing frequency during the past few years by reconstructive surgeons to help salvage ischaemic tissues. We aim to summarise the anatomy, physiology, and pharmacological mechanisms of action of leeches to provide reconstructive surgeons with a theoretical basis for their use.

(c) 2004 The British Association of Oral and Maxillofacial Surgeons. Published by Elsevier Ltd. All rights reserved.
\end{abstract}

\section{Introduction}

Blood letting and the therapeutic use of Hirudo medicinalis dates back to ancient Egypt and the beginnings of civilisation. ${ }^{1}$ The popularity of the annelid has varied throughout the ages depending on the incumbent beliefs of the medical hierarchy. In

* Corresponding author. Present address: 3, Magellan House, Armouries Way, Leeds LS10 1JE, UK. Tel.: +44 1619627563.

E-mail address: iain_Whitaker@yahoo.com (I.S. Whitaker). recent years leeches have enjoyed a renaissance in the world of reconstructive microsurgery. The first reported modern day use of leeches for alleviating venous engorgement following flap surgery was published by Derganc and Zdravid in 1960.2 Their series of 20 pedicled flaps reported that the use of leeches assisted them to achieve a $70 \%$ complete salvage rate. Since then, there have been many case reports describing the successful use of leeches to alleviate venous congestion. The survival of compromised, venous-congested tissues is 
improved by early application of a leech. ${ }^{3-7}$ The most common indications for leeches include the salvage of compromised microvascular free-tissue transfers, ${ }^{8,9}$ replanted digits, ${ }^{10}$ ears, ${ }^{11}$ lips, ${ }^{12,13}$ scalps, ${ }^{14}$ and nasal tips. ${ }^{15}$ Foucher reported in 1981 that 6 of 10 artery-only distal replantations of digits survived with the aid of leeches, a significant improvement over treatment with systemic anticoagulants alone. ${ }^{10}$ Further information on the use of leeches in clinical practice, their complications, and a suggested protocol for their use can be found elsewhere. ${ }^{4}$

\section{Anatomy of the leech}

The leech belongs to the phylum Annelida, a group that includes earthworms and several other members. There are more than 700 species of leech, all of which are carnivorous and move using suckers Leeches are hermaphrodite and contain both male and female sexual organs, but they have no ability to self-fertilise. $H$. medicinalis, endemic to the swamp lands of south-east Asia and Europe, is the most useful species medically, ${ }^{16}$ because of their ability to bite deeply and to cause prolonged bleeding from the wound after they are detached. $H$. medicinalis can reach up to $12 \mathrm{~cm}$ long, but is typically about a third of this size and weighs about $1-1.5 \mathrm{~g}$ before it feeds. It is composed of around 102 segments with 5 annuli in each segment except at each tapered end where there are fewer annuli. Its surface is covered by a thin distensible cuticle and outer mucinous coating, which allows the leech to expand when it has fed.

The narrower tapered end is its head and the opposite larger disc-like end is its bottom. Sucking devices are present at both ends. The posterior end consists of a large muscular organ for attachment and crawling. The anterior, smaller, and more mobile end is the head. The bite is created by three jaws, each containing $60-100$ pairs of cutting teeth, forming the characteristic Y-shaped triradiate conformation $1 \mathrm{~mm}$ in diameter and up to $1.5 \mathrm{~mm}$ in depth. ${ }^{17,18}$ The leech has a simple internal anatomy, consisting of a straight tubular digestive tract with diverticula.

\section{Feeding}

A potential host is identified by its movement and production of heat, and sweat and blood are detected by chemoreceptors on the leech's anterior sucker. Attachment and the start of feeding de- pend on a number of mechanical and chemical factors, including warmth, concentrations of sodium and arginine on the skin, whether the leech is hungry, and whether there is blood on the surface. ${ }^{19}$ A combination of these factors causes serotonindependent stimulation of peripheral neurons in the leech's pharynx and stimulates feeding behaviour. ${ }^{20}$ The feeding behaviour of a leech, in addition to blood, can also be stimulated by a glucose in saline solution, l-arginine, and serotonin. ${ }^{21}$ Biting is usually at temperatures between $33^{\circ}$ and $40^{\circ} \mathrm{C}$ and they rarely bite below $25^{\circ} \mathrm{C} .{ }^{22}$

While it is feeding the leech secretes a number of active chemicals into the wound from unicellular salivary ductules situated at the leading edge of the jaw (Table 1). These facilitate prolonged bleeding from the wound, and allow the leech adequate time to acquire a full meal of blood uninhibited by clotting. Secretions during a single feed can prevent in vitro coagulation of up to $100 \mathrm{ml}$ of human blood. ${ }^{23}$ Bite of a leech is painless, although the presence of a local anaesthetic in the secretion is debated, and no such substance has yet been found. The reported volume of blood in each meal varies widely, from $1.3 \mathrm{ml}$ to as much as $50 \mathrm{ml} .^{24}$ Similarly, the reported volume of passive bleeding after detachment of the leech, and its duration, varies widely. Volumes range from 2 to $50 \mathrm{ml}$, and passive bleeding has been reported to continue from $1 \mathrm{~h}$ up to $72 \mathrm{~h}$ after detachment. Conforti et al. in a porcine model of venous congestion, found that the mean volume of blood in a meal was $2.4 \mathrm{ml}$.

Ninety percent of passive bleeding occurred within $5 \mathrm{~h}$, and the mean loss al $4 \mathrm{~h}$ was $2.5 \mathrm{ml} .{ }^{24} \mathrm{No}$ proteolytic enzymes have been identified in the gut of $H$. medicinalis. The digestive tract is colonised by several symbiotic bacteria, which are thought to digest blood and to protect it from purification. Aeromonas hydrophila has been identified as the predominant bacterium, and Serratia, Klebsiella and Pseudomonas have also been isolated. ${ }^{25}$ The benefit of prophylactic antibiotics during treat-

Table $1 H$. medicinalis physiologically active salivary products.

\begin{tabular}{ll}
\hline Mechanism & Identified products \\
\hline "Permeability" factors & $\begin{array}{l}\text { Hyaluronidase; } \\
\text { collagenase } \\
\text { Histamine-like product }\end{array}$ \\
$\begin{array}{l}\text { Vasodilation } \\
\text { Inhibition of platelet } \\
\text { aggregation }\end{array}$ & $\begin{array}{l}\text { Calin, apyrase, saratin } \\
\text { Inhibition of the coagu- } \\
\text { lation cascade } \\
\text { Proteinase inhibitors }\end{array}$ \\
\hline
\end{tabular}


ment with leeches has been reported. ${ }^{26}$ Water is extracted from the blood meal and excreted through 17 pairs of ventrally located nephridia. The digestive process lasts up to 3 months and the leech may not require feeding for up to a year after a full blood meal. ${ }^{27}$

\section{Salivary secretions}

The best known salivary product of the leech is hirudin, one of the most potent natural anticoagulants. Hirudin was first isolated and named by Haycroft in $1884 .{ }^{28}$ Its chemical analysis was completed in 1955, and it was identified as a 65 amino acid polypeptide with specific activity as a direct inhibitor of thrombin. ${ }^{29}$ Hirudin has a low molecular weight of 9000 , and is a specific non-enzymatic inhibitor of thrombin. Thrombin has two main roles in the coagulation process: it stimulates the release of platelet activation factor (PAF) and is the enzyme responsible for the universal final step in the coagulation cascade. In this step, fibrinogen is converted to fibrin, which acts to stabilise clots by forming cross-linking strands. Hirudin inactivates thrombin by blocking substrate-binding groups, which prevents other molecules binding to its saturable sites. ${ }^{30}$

In vitro studies have suggested that hirudin also inhibits active Factor X (Fig. 1). ${ }^{31}$ As an anticoagulant, hirudin has specific advantages over heparin in that it does not require antithrombin III for its activity, and it is not affected by heparin-neutralising

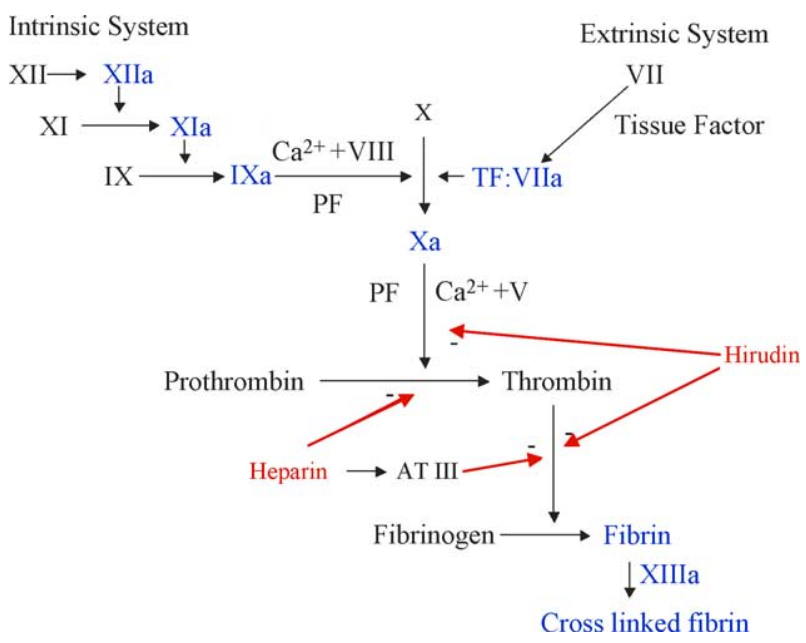

Figure 1 Effect of hirudin and heparin on the coagulation cascade. Heparin inhibits the conversion of prothrombin to thrombin and also inhibits the activity of thrombin by anti-thrombin III (AT-III). Hirudin has a direct inhibitory effect on thrombin, and may also have activity against activated Factor $\mathrm{X}$. platelet factor 4 , which is released during the coagulation process. Unlike heparin, hirudin does not interfere with biosynthesis of clotting factors, or affect other enzyme pathways such as that of lipoprotein lipase. However, resistance has been reported in laboratory animals after repeated exposures. Toxicity, antigenicity, and anaphylaxis have been described after the use of hirudins, although their overall risk:benefit ratio is favourable. ${ }^{32}$ Derivatives of hirudin, including lepirudin and bivalirudin have been produced and cloned using recombinant technology. These have been tested in numerous clinical trials of anticoagulation for acute coronary syndromes, percutaneous coronary interventions, and prophylaxis of deep vein thrombosis. ${ }^{33,34}$

Lepirudin is licensed in the UK for anticoagulation in patients who have heparin-induced thrombocytopenia. Hirudin derivatives are also available commercially as topical preparations for conditions such as bruising, superficial thrombophlebitis, chilblains, and varicose veins. Hirudin itself does not account fully for the prolonged bleeding that occurs after leeches have taken a blood meal; several other proteins have been isolated that have vasoactive effects on the microcirculation. Hyaluronidase is a beta-endoglucoronidase, which, together with an unidentified collagenase, increases overall tissue permeability and ensures maximum penetration of the salivary secretions. ${ }^{35}$ A histamine-like vasodilator acts synergistically to increase regional blood flow. The saliva of $H$. medicinalis also contains various proteinase inhibitors, including bdellin (a plasmin inhibitor), trypsin, and eglin (inhibitors of chymotrypsin and elastase). ${ }^{36}$ The secretions of $H$. medicinalis also inhibit platelet aggregation. Normally, when the endothelium is injured, platelets come into contact with subendothelial collagen, which triggers activation of platelets, recruitment of additional platelets, and secretion of vasoactive substances that start the coagulation cascade. ${ }^{37}$ The initial activation of platelets is thought to be inhibited by several proteins found in the saliva of $H$. medicinalis, including calin and apyrase. ${ }^{38-40}$ Human platelet aggregation, induced in vitro by ADP, is inhibited by the leech's salivary secretions. ${ }^{41}$ Saratin is a copy of a protein recently isolated from the saliva of $H$. medicinalis which also has antiplatelet activity. It is thought to act by binding to collagen, and inhibiting the interaction between von Willebrand factor and collagen under conditions of increased shear (Fig. 2). ${ }^{42}$ Saratin therefore inhibits adherence and adhesion of platelets to the vessel wall.

There has been much interest in saratin in vascular surgery, where its topical application signifi- 

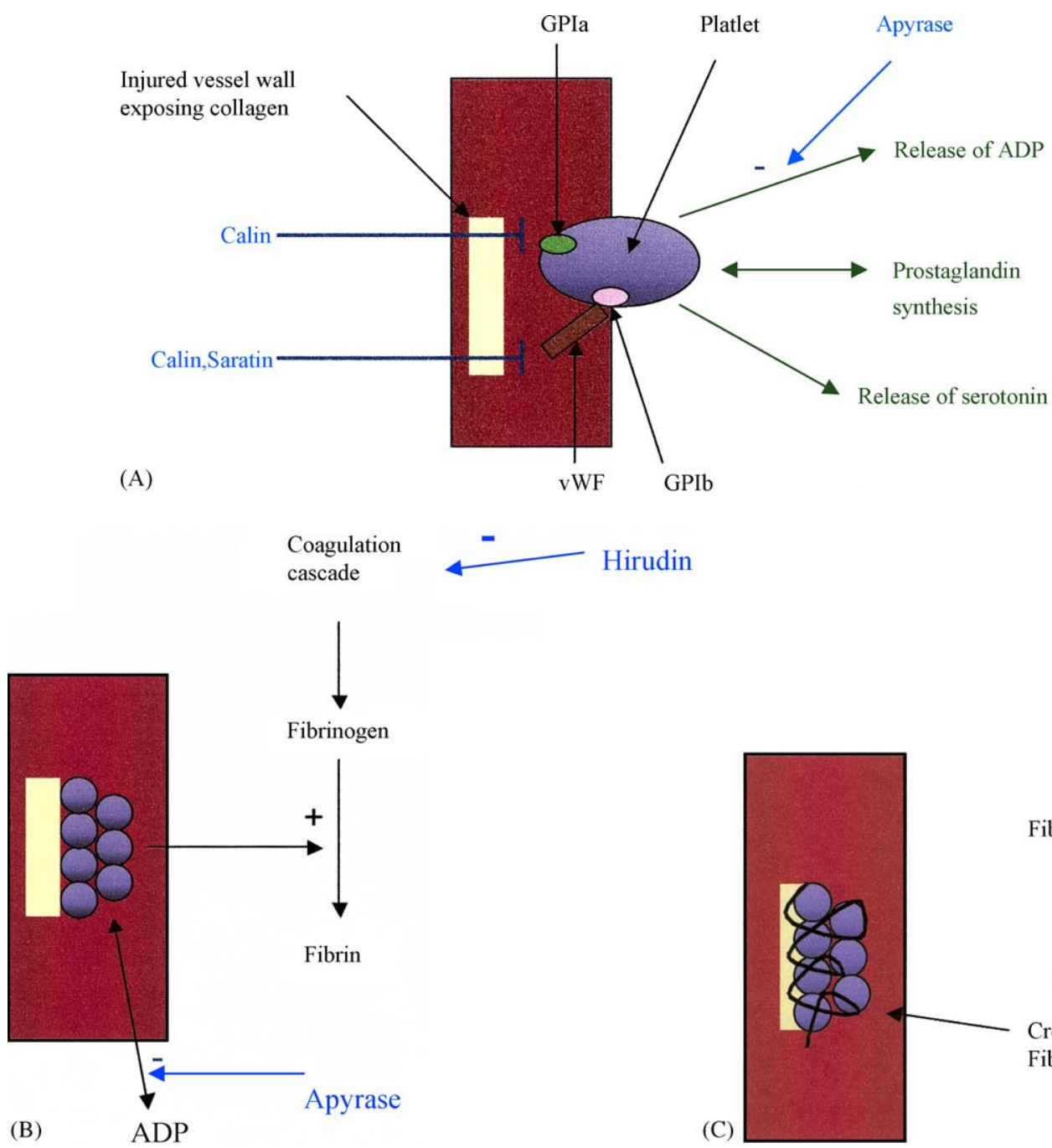

Figure 2 (A) Interaction between platelets and collagen. Injury to the vessel wall exposes collagen, which causes platelet adhesion dependent on platelet membrane receptors. After adhesion, prostaglandin synthesis is stimulated, promoting release of contents of the cytoplasmic granules, including ADP, serotonin and several other factors. Serotonin causes local vasoconstriction, while ADP triggers platelet aggregation, and formation of the platelet plug. (B and $C$ ) The coagulation pathway is stimulated leading to formation of fibrin, which stabilises the platelet plug.

cantly reduces complications of platelet adhesion, intimal hyperplasia, luminal stenosis, and thrombosis in rat experimental models. ${ }^{43}$ Saratin has also been studied in a canine model of prosthetic access for dialysis, in which topical application significantly reduced intimal hyperplasia and the risk of stenosis. ${ }^{44}$

\section{Hirudo medicinalis: technical tips and psychological issues}

A suggested protocol for the general use of leeches can be found elsewhere. ${ }^{4}$ The application of leeches to intraoral flaps is unique, and care must be taken to facilitate successful attachment. The leech's propensity to migrate after attachment has caused problems in the past. Obstruction of upper airways has been described after migration of leeches to the hypopharynx where they became engorged with blood, and haemoptysis has been reported after migration to the bronchus. ${ }^{45} \mathrm{~A}$ suggestion from an eminent maxillofacial surgeon to get around this problem involves suturing of the 'sucker pad' (as opposed to the mouth end) to the skin of the flap once the leech starts feeding. This seems to stop its migration it has been reported that about half of all patients are counselled routinely before leeches are applied, and information sheets are available in a few units. The services of a clinical psychologist are rarely available. Only a small number of patients refuse to have leeches, ${ }^{3,4}$ per- 
haps because they are so unwell and fearful of losing their flap, that they are happy to accept these measures as a last resort.

\section{Hirudo medicinalis and free-tissue transfers}

Microvascular free-tissue transfer is now common. Despite its high success rate, about $8-10 \%$ require re-exploration when the viability of the flap is threatened. ${ }^{46}$ Venous thrombosis is more common than arterial thrombosis. ${ }^{47}$ Various methods of monitoring of the flap are in use at present but we are still searching for the ideal technique. ${ }^{48}$ It has been shown in experimental flaps that acute venous obstruction is more damaging than acute and complete obstruction of the pedicle, where both arterial and venous supplies are affected. ${ }^{49,50}$ In a porcine latissimus dorsi model, venous occlusion led to necrosis of $40 \%$ of muscle fibres after $3 \mathrm{~h}$, compared with no necrosis after arterial occlusion. ${ }^{51}$ Histological studies have shown that venous obstruction causes microcirculatory thrombosis, trapping of platelets, and stasis. Even after successful reanastomosis, changes in the microcirculation may persist, preventing re-establishment of normal circulation. The management of the venouscompromised flap are divided into surgical and non-surgical techniques, and include application of leeches, hyperbaric oxygen, and thrombolytic treatment. Without treatment, the congested tissue becomes ischaemic, leading to necrosis of tissues. A randomised control trial of leech-treated venous-compromised rodent epigastric skin flaps showed a significant increase in flap survival rate. ${ }^{52}$ In a leech-treated porcine model of venous compromised flaps, improved blood flow was shown objectively by laser Doppler perfusion studies. After replantation of a human ear, quantitative measurements of blood flow using injected fluorescein showed an improvement in venous congestion after application of leeches. ${ }^{53}$ The increased blood flow is thought to result from a combination of bleeding, which relieves obstruction and raises capillary pressure, and effects on the microcirculation caused by injection of the leech's vasoactive secretions.

Recent experimental studies have shown that angiogenic growth factors such as vascular endothelial growth factor (VEGF) may promote neovascularisation of a flap. ${ }^{54}$ Kubo et al. postulated that VEGF, in combination with an exanguination technique such as leeching and hyperbaric oxygen may further increase the survival of flaps. ${ }^{47}$ A recent study of a rodent venous occlusion model has shown a significant increase in survival of flaps that were treated with a combination of leeches and hyperbaric oxygen $(67 \%$ survival) compared with leeching alone (25\%). ${ }^{55} \mathrm{Hy}$ perbaric oxygen alone was not an effective treatment, resulting in only $1 \%$ of flaps surviving.

\section{References}

1. Whitaker IS, Rao J, Izadi D, Butler PE. Hirudo medicinalis: ancient origins, and trends in the use of medicinal leeches throughout history. Br J Oral Maxillofac Surg 2004;42:133-7.

2. Derganc $M$, Zdravid $F$. Venous congestion of flaps treated by application of leeches. Br J Plast Surg 1960;13:187-92.

3. Rao J, Whitaker IS. Use of Hirudo medicinalis by maxiliofacial surgery units in the UK: current views and practice. $\mathrm{Br}$ J Oral Maxillofac Surg 2003;41:54-5.

4. Whitaker IS, Izadi D, Oliver DW, Monteath G, Butler PE. Hirudo medicinalis and the plastic surgeon. Br J Plast Surg 2004;57:348-53.

5. De Chalain TM. Exploring the use of the medicinal leech: a clinical risk-benefit analysis. $J$ Reconstr Microsurg 1996;12:165-72.

6. Hayden RE, Phillips JG, McLear PW. Leeches. Objective monitoring of altered perfusion in congested flaps. Arch Otolaryngol Head Neck Surg 1988;114:1395-9.

7. Lee C, Mehran RJ, Lessard ML, Kerrigan CL. Leeches: controlled trial in venous compromised rat epigastric flaps. $\mathrm{Br}$ J Plast Surg 1992;45:235-8.

8. Utley DS, Koch RJ, Goode RL. The failing flap in facial plastic and reconstructive surgery: role of the medicinal leech. Laryngoscope 1998;108:1129-35.

9. Batchelor AGG, Davison P, Sully L. The salvage of congested skin flaps by the application of leeches. $\mathrm{Br} J$ Plast Surg 1984;34:358-60.

10. Foucher G, Henderson HR, Maneau M, Merie M, Braun FM. Distal digital replantation: one of the best indicators for microsurgery. Int J Microsurg 1981;3:265-70.

11. Cho BH, Ahn HB. Microsurgical replantation of a partial ear, with leech therapy. Ann Plast Surg 1999;43:427-9.

12. Walton RL, Beahm EK, Brown RE, et al. Microsurgical replantation of the lip: a multi-institutional experience. Plast Reconstr Surg 1998;102:358-68.

13. Hirase $Y$, Kojima T, Hayashi J, Nakano M. Successful upper labial replantation after 17 hours of ischemia: case report. $J$ Reconstr Microsurg 1993;9:327-9.

14. Henderson HP, Matti B, Laing AG, et al. Avulsion of the scalp treated by microvascular repair: The use of leeches for post-operative decongestion. Br J Plast Surg 1983;36:235-9.

15. Mortenson BW, Dawson KH, Murakami C. Medicinal leeches used to salvage a traumatic nasal flap. Br J Oral Maxillofac Surg 1998;36:462-4.

16. Utley DS, Koch J, Goode RL. The failing flap in facial plastic and reconstructive surgery: role of the medicinal leech. Laryngoscope 1998;108:1129-35.

17. Sawyer RT. Feeding and digestive system. Leech biology and behaviour, vol. 2. Oxford: Clarendon Press; 1986. p. 467-518.

18. Kraemer BA, Korber KE, Aquino TI, Engleman A. Use of leeches in plastic and reconstructive surgery: a review. $J$ Reconstr Microsurg 1988;4:381-6.

19. Lent C. New medical and scientitic uses of the leech. Nature 1986;323:494. 
20. Lent CM. Serotonergic modulation of the feeding behaviour of the medicinal leech. Brain Res Bull 1985;14:643-55.

21. Lent $\mathrm{CM}$, Dickinson $\mathrm{MH}$. The neurobiology of feeding in leeches. Sci Am 1988;258:98-103.

22. Lent CM, Dickinson MH. On the termination of ingestive behavior by the medicinal leech. J Exp Biol 1987;131:1-15.

23. Mory RN, Mindell D, Bloom DA. The leech and the physician: biology, etymology, and medical practice with Hirudinea medicinalis. World J Surg 2000;24:878-83.

24. Conforti ML, Connor NP, Heisey DM, Hartig GK. Evaluation of performance characteristics of the medicinal leech (Hirudo medicinalis) for the treatment of venous congestion. Plast Reconstr Surg 2002;109:228-35.

25. Lineaweaver WC. Aeromonas hydrophila infections following clinical use of medicinal leeches: a review of published cases. Blood Coagul Fibrinolysis 1991;2:201-3.

26. Whitaker IS, Elmiyeh B, Wright DJ. Hirudo medicinalis: The need for prophylactic antibiotics. Plast Reconstr Surg 2003;112:1185-6.

27. Wells MD, Manktelow RT, Boyd IB, Bowen V. The medical leech: an old treatment revisited. Microsurgery 1993;14:183-6.

28. Haycroft JB. On the action of secretion obtained from the medical leech on the coagulation of blood. Proc $R$ Soc Lond 1884;36:478-87.

29. Markwardt F. Pharmacology of hirudin: one hundred years after the first report of the anticoagulant agent in leeches. Biomed Biochim Acta 1985;44:1007-13.

30. Markwardt F, Hauptmann J, Nowak G, Klessen C, Walsmann P. Pharmacological studies on the anti-thrombotic action of hirudin in experimental animals. Thromb Haemost 1982;47:226-9.

31. Brown JE, Baugh RF, Hougie C. Inhibition of the intrinsic generation of activated Factor $\mathrm{X}$ by heparin and hirudin. Thromb Res 1980;17:267-72.

32. Greinacher A, Lubenow N, Eichler P. Anaphylactic and anaphyiactoid reactions associated with iepirudin in patients with heparin-induced thrombocytopenia. Circulation 2003;108:2062-5.

33. White HD, Chew DP. Bivalirudin an anticoagulant for acute coronary syndromes and coronary interventions. Expert Opin Pharmacother 2002;3:777-88.

34. Cheng-Lai A. Cardiovascular drug highlight: hirudin. Heart Dis 1999;1:41-9.

35. Rigbi $M$, Orevi $M$, Eldor A. Platelet aggregation and coag ulation inhibitors in leech saliva and their roles in leech therapy. Semin Thromb Hemost 1996;22:273-8.

36. Baskova IP, Zavalova LI. Proteinase inhibitors from the medicinal leech Hirudo medicinalis. Biochemistry (Mosc) 2001;66:703-14.

37. Johnson PC. Platelet-mediated thrombosis in microvascular surgery. Plast Reconstr Surg 1990;86:350-67.

38. Rigbi $M$, Levy $H$, Eldor $A$, et al. The saliva of the medicinal leech Hirudo medicinalis-II. Comp Biochem Physiol 1987;88C:95-8.

39. Harsfalvi J, Stassen JM, Hoylaerts MF, et al. Calin from Hirudo medicinalis, an inhibitor of von Willebrand factor binding to collagen under static and flow conditions. Blood 1995; 85:705-11.

40. Eldor A, Orevi $M$, Rigbi $M$. The role of the leech in medical therapeutics. Blood Rev 1996;10:201-9.

41. Baskova IP, Missel'vitz F, Nikonov GI, Novikov ID, Leitin VL. Salivary gland secretion of the leech Hirudo medicinalis inhibits ADP-induced of human platelets and platelet adhesion to a collagen-coated surface. Biul Eksp Biol Med 1984;97:696-9.

42. Barnes CS, Krafft B, Freeh M, et al. Production and characterization of saratin, an inhibitor of von Willebrand factordependent platelet adhesion to collagen. Semin Thromb Hemost 2001;27:337-48.

43. Cruz CP, Eidt J, Drouilhet J, et al. Saratin, an inhibitor of von Willebrand factor-dependent platelet adhesion, decreases platelet aggregation and intimal hyperplasia in a rat carotid endarterectomy model. J Vasc Surg 2001;34:724-9.

44. Smith TP, Alshafie TA, Cruz CP, et al. Saratin, an inhibitor of collagen-platelet interaction, decreases venous anastomotic intimal hyperplasia in a canine dialysis access model. Vasc Endovascular Surg 2003;37:259-69.

45. Almallah Z. Internal hirudiniasis as an unusual cause of haemoptysis. Br J Dis Chest 1968;62:215-8.

46. Khouri RK, Cooley BC, Kunselman AR, et al. A prospective study of microvascular free-flap surgery and outcome. Plast Reconstr Surg 1998;102:711-21.

47. Kubo T, Yano K, Hosokawa K. Management of flaps with compromised venous outflow in head and neck microsurgical reconstruction. Microsurgery 2002;22:391-5.

48. Whitaker IS, Oliver DW, Ganchi P. A post-operative monitoring of microvascular free tissue transfers: current practice in the UK and Ireland. Plast Reconstr Surg 2003;111:2118-9.

49. Su C-T, Im MJ, Hoopes JE. Tissue glucose and lactate following vascular occlusion in island skin flap. Plast Reconstr Surg 1982;70:202-5.

50. Angel MF, Mellow CG, Knight KR, O’Brien BMCC. Secondary ischemia time in rodents: contrasting complete pedicle interruption with venous obstruction. Plast Reconstr Surg 1990;85:789-93.

51. Kerrigan CL, Wizman P, Hjortdal VE, Sarnplis J. Global flap ischaemia: a comparison of arterial versus venous etiology. Plast Reconstr Surg 1994;93:1485-95.

52. Lee $C$, Mehran RJ, Lessard M-L, Kerrigan CL. Leeches: controlled trial in venous compromised rat epigastric flaps. $\mathrm{Br}$ J Plast Surg 1992;45:235-8.

53. Anthony JP, Lineaweaver WC, Davis JW, Buncke HJ. Quantitative fluorimetric effects of leeching on a replanted ear. Microsurgery 1989;10:167-9.

54. Lubiatowski P, Goldman CK, Gurunluoglu R, et al. Enhancement of epigastric skin flap survival by adenovirus-mediated VEGF gene therapy. Plast Reconstr Surg 2002;109: 1986-93.

55. Lozano DD, Stephenson LL, Zamboni WA. Effect of hyperbaric oxygen and medicinal leeching on survival of axial skin flaps subjected to total venous occlusion. Plast Reconstr Surg 1999;104:1029-32.

Available online at www.sciencedirect.com

science 0 Direct? 